\title{
Antimicrobial Effects of Bitter Kola (Garcinia Kola) Nut on Staphylococcus Aureus, Eschererichia Coli and Candida Alibicans
}

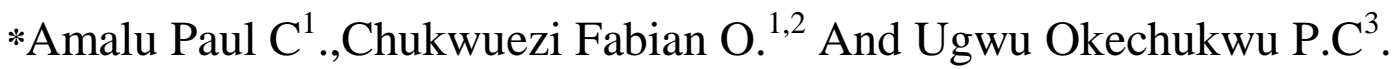 \\ ${ }^{I}$ Department Of Medical Laboratory Sciences, Faculty Of Health Sciences And Technology College Of \\ Medicine, University Of Nigeria, Nsukka. \\ ${ }^{2}$ Department Of Biological Sciences, Faculty Of Applied And Natural Sciences, Tansian University, Umunya. \\ ${ }^{3}$ Department Of Biochemistry, Tansian University, Umunya.
}

\begin{abstract}
This study was conducted to test for the antimicrobial activity of Garcinia kola (Aku-inu) against some microbial organisms, namely: Staphylococcus aureus, Escherichia coli and Candida albicans. The paper disc method was used to determine the inhibitory effect of Garcinia kola nut on the test micro-organisms. The zones of inhibition for Staphylococcus aureus ranged between 0.5 to $5 \mathrm{~mm}$ for the ethanol preparation of Garcinia kola nut while that of E. coli ranged between 0.3 to $3.2 \mathrm{~mm}$. The ethanol preparation of Garcinia kola nut was found to exhibit more significant inhibitory action against test organisms than the aqueous preparations of Garcinia kola nut. Staphylococcus aureus in both preparations gave wider zones of inhibition than E.coli while Candida albicans exhibited no response. Minimal zones of inhibition started from $40 \%$ ethanol and diameter of inhibition increases with increase in ethanol concentration for E.coli, while Staphylococcus aureus started from $20 \%$ ethanol increasing in diameter as the concentration of ethanol increases. Candida albicans showed no zone of inhibition. Minimal zones of inhibition for the different weights of Garcinia kola nut/disc in $1 \mathrm{ml}$ of aqueous preparation of Garcinia kola nut started from the discs containing $300 \mu \mathrm{g}$ and $400 \mu \mathrm{g}$ for Staph. aureus and E. coli respectively, with diameters of $0.3 \mathrm{~mm}$ and $0.4 \mathrm{~mm}$. Candida albicans showed no response to the different weights of Garcinia kola nut per ml of water. Statistically, results showed that ethanol preparation of Garcinia kola nut exhibit more significant activity $(p<0.001)$ than the aqueous preparation of Garcinia kola nut $(p<0.01)$. The results of the Garcinia kola nut may be attributed to the presence of some pharmacokinetic compounds.
\end{abstract}

Keywords: Garcinia kola, Candida albicans, Staphylococcus aureus, E.coli and Minimal zones of inhibition.

\section{Introduction}

The Nigeria climate favours a great array of plant species many of which have varied medicinal and antimicrobial potentials [1, 2, 3, 4 and 5]. It is estimated that there are over 65,000 species of flowering plants that have medicinal properties [6, 7, 8, 9 and 10]. In African, medicinal plants constitute a rich but still largely untapped pool of natural products. Many countries from the developing world are still dependent on medicinal plants for treating the sick among them. Globally, the last two decades has witnessed an unprecedented increase of drug resistance by pathogenic micro-organisms as well as the appearance of undesirable side effect of certain antibiotics [11 and 12]. Other limitations of modern chemotherapeutic drugs are their high cost and nonavailability, especially in rural areas. As a consequence, it is necessary to search for new organic molecules with antimicrobial activity, which in addition could be potential sources for starting materials for the semi-synthesis of new drugs [12 and 13]. Traditional medicine practice is an important part of health care delivery system in most part of the developing world $[14,15,16$ and 17] and is a source of primary health care to $80 \%$ of the worlds' population [18 and 19]. Traditional medical knowledge of medicinal plants and their use by indigenous culture are not only useful for conservation of cultural traditions and biodiversity but also for community healthcare and drug development now and in the future [20,21, 22 and 23]. Traditional herbalist in Nigeria uses a variety of herbal preparation to treat different kinds of ailmentssuch as gonorrhea, sore throat and skin infections like eczema. This has been the case ever before the introduction of antibiotics and other modern drugs into Africa [24, 25, 26, 27 and 30].

According to the World Health Organization (WHO), up to $80 \%$ of the population in Africa depends on traditional herbal medicine for primary health care, accounting for around $20 \%$ of the overall drug market [31 and 32]. A number of plants that have medicinal and antimicrobial properties in Nigeria have been identified and documented [33 and 34]. World- wide increase in resistance to antibiotics has prompted scientists and researchers to seek for other possible potential antimicrobials [35 and 36]. Due to this search, plants have been seen as a good source of antimicrobial agents[37]. Some of the active ingredients of the extracts of some plants have been isolated, tested and documented [4 and 8].

The clinical efficacy of many existing antibiotics is being threatened by the emergence of multidrugresistant pathogens. The increasing failure of chemotherapeutic and antibiotic resistance exhibited by pathogenic 
microbial agents has led to the screening of several medicinal plants for their potential antimicrobial activity [20 and 28]. In Africa, the tremendous diversity of plants partly explains the popularity of traditional medicine and the wide variety of medicinal recipes utilized by traditional healers. In a situation where at least 855 of African population in both urban and rural areas, regardless of their socio - cultural background, resort to traditional medicine to treat their sick and alleviate suffering, there is an urgent need to undertake a scientific inventory of the available medicinal plants used by traditional healers. Plants have been major sources of medicine and plant secondary metabolites have been attributed for most plants therapeutic activities [7, 8, 9 and 13].

\section{AIMS AND OBJECTIVES}

1. To note the probable antimicrobial effects of Garcinia kola nut on isolated microorganisms.

2. To make appropriate recommendations for further development and effective application of Garcinia kola nut.

\section{Materials And Methods}

Collection of sample:Garcinia kola nuts were obtained at main Market, Onitsha. The seeds were peeled and cut into pieces, dried and then ground into a powder [27]. This study was conducted at FEZI laboratory, Onitsha between the periods May to July, 2012.

Isolation of Test Organisms: Standard test organisms were isolated from FEZI laboratory, Onitsha, Anambra State, Nigeria. Both the ethanol and aqueous preparations were made according to [22].

Preparation of Aqueous Suspension of Garcinia kola: Different weights of ground Garcinia kola nuts (1g, 2g, $3 \mathrm{~g}, 4 \mathrm{~g}, 5 \mathrm{~g}$ and $6 \mathrm{~g}$ ) were dissolved in separate sterile containers of watereach and allowed to stand at room temperature with intermittent shaking for 4days.

\section{Antimicrobial Sensitivity test with Aqueous Suspension of Garcinia kola}

The paper disc method was used as described by [22]. Sterile paper discs (100 paper discs) were soaked in each container of different aqueous suspensions of Garcinia kola. This was mixed thoroughly and allowed to dry for 1h.Nutrient Agar and Sabouraud Dextrose Agar Plates were prepared and dried in an oven. Overnight peptone suspension of Staph.aureus and E.coli and Sabouraud broth suspension of C. albicans were prepared. Two milliliters (2mls) from each peptone culture of Staph.aureus and E. coli were flooded onto Nutrient Agar plates for the sensitivity test. Discs containing the different weights of ground Garcinia kola nuts were aseptically placed onto the surface of Nutrient agar plates and Sabouraud Dextrose Agar plate in an increasing order of weights of ground Garcinia kola nuts. Discs containing water alone were used as negative control.

Antimicrobial Sensitivity Test with Ethanol Suspension Garcinia Kola: Hundred sterile discs were soaked in $1 \mathrm{ml}$ of each of the different ethanol suspension of Garcinia kola and allowed for $1 \mathrm{~h}$ for proper absorption. Disc

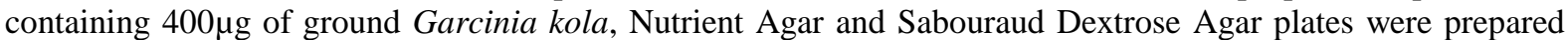
and dried in an oven. Overnight peptone suspension of Staph.aureus and E.coli and Sabouraud broth suspension of $C$. albicans were prepared. Two milliliters (2mls) from each peptone culture of Staph.aureus and E. coli were flooded onto Nutrient Agar plates for the sensitivity testing of Staph. aureus and E. coli. 2mls of Sabouraud suspension of $C$. albicanswas also flooded onto Sabourated Dextrose Agar plate. Discs containing the $400 \mu \mathrm{g}$ of ground Garcinia kola were aseptically placed onto the surfaces of nutrient agar plates and incubated at $37^{\circ} \mathrm{C}$ for $18 \mathrm{~h}$ while the SabouraudDetrose Agar plates was incubated at room temperature overnight.

\section{Results}

TABLE 1: ANTIMICROBIAL ACTIVITIES OF DIFFERENT GRADES OF ETHANOL SUSPENSION OF GARCINIA KOLA (GKN).

\begin{tabular}{|c|c|c|c|}
\hline \multirow[t]{2}{*}{ Weight of $400 \mu \mathrm{g}$ GKN/disc } & \multicolumn{3}{|c|}{ Zones of inhibition (mm) } \\
\hline & $\mathbf{S a}$ & Ec & $\mathbf{C a}$ \\
\hline $20 \%$ ethanol & 0.5 & - & Nil \\
\hline $30 \%$ ethanol & 1.5 & - & - \\
\hline $40 \%$ ethanol & 2.0 & 1.0 & - \\
\hline $50 \%$ ethanol & 2.3 & 1.3 & - \\
\hline $60 \%$ ethanol & 4.2 & 3.0 & - \\
\hline $70 \%$ ethanol & 5.0 & 3.5 & - \\
\hline
\end{tabular}

KEY

$\mathrm{Sa}=$ Staphylococcus aureus; $\mathrm{Ec}=$ Escherichia coli $; \mathrm{Ca}=$ Candida albicans; $\mathrm{GKN}=$ Garcinia Kola Nut. 
Table 2: Antimicrobial activity of aqueous Garcinia kola suspension

\begin{tabular}{|c|c|c|c|}
\hline \multirow[t]{2}{*}{$\begin{array}{l}\text { Weights }(\mu \mathrm{g}) \text { of GK/ disc } \\
\text { In 1ml of aqueous GKS }\end{array}$} & \multicolumn{3}{|c|}{$\begin{array}{l}\text { Zones of } \\
\text { inhibition }(\mathbf{m m})\end{array}$} \\
\hline & $\mathbf{S a}$ & Ec & $\overline{\mathbf{C a}}$ \\
\hline 100 & - & - & Nil \\
\hline 200 & - & - & - \\
\hline 300 & 0.3 & - & - \\
\hline 400 & 2.5 & 0.4 & - \\
\hline 500 & 3.0 & 1.3 & \\
\hline 600 & 3.2 & 1.5 & \\
\hline
\end{tabular}

\section{KEY \\ $\mathrm{Sa}=$ Staphylococcus aureus $; \mathbf{E c}=$ Escherichia coli $; \mathbf{C a}=$ Candida albicans; $\mathbf{G k}=$ Garcinia kola; GKS= Garcinia kola suspension}

\section{Discussion}

The results of this research showed that Garcinia kola nut possess some degree of inhibitory effects against the microorganisms- Staphylococcus aureus and E.coli with no inhibitory effect on Candida albicans. From table 1 above, there was a corresponding increase in the zones of inhibition of Staph. aureus and E. coli as the strength of $1 \mathrm{ml}$ ethanol suspension of $400 \mu \mathrm{g}$ Garcinia kola nut per disc increases. Staphylococcus aureus gave wider zones of inhibition that ranged from $0.5 \mathrm{~mm}$ to $5.0 \mathrm{~mm}$ while that of $E$. coliranged between $1.0 \mathrm{~mm}$ to $3.5 \mathrm{~mm}$. Candida albicans showed no response at the different strength of $1 \mathrm{ml}$ ethanol suspension of $400 \mu \mathrm{g}$ Garcinia kola nut per disc.

From Table 2, there was an increase in the zones of inhibition of Staphylococcus aureus and E. coli with an increase in the weights of suspension. The zones of inhibition for Staphylococcus aureus ranged from $0.4 \mathrm{~mm}$ to $1.5 \mathrm{~mm}$. Candida albicans showed no response at different weights of Garcinia kola nut per disc in $1 \mathrm{ml}$ of aqueous Garcinia kola nut suspension. The minimal zone of inhibition recorded for Staphylococcus aureus was $0.3 \mathrm{~mm}$ at weights of $300 \mu \mathrm{g}$ Garcinia kola nut/disc in $1 \mathrm{ml}$ aqueous Garcinia kola nut suspension.

G .kola (bitter kola) seed is believed to be effective in treating throat infections and cough [20, 25 and 30]. Moreover, bitter kola has also been identified to have strong antibiotic activities and found to be very effective against disease causing micro-organisms such as E. coli,Staph. aureus, Salmonella spp. Streptococcus spp, Vibrio choleraand Gonorrhoea [11, 15, 23 and 25].

Since the plant produced good inhibition zones against the test organisms, it is expected that they could be used to treat infections and diseases caused by these organisms and if the active ingredients are isolated and possibly crystallized, therapeutic antibiotics could be produced from the plant [4, 7, 9 and 11].

\section{Conclusion}

The results of this study showed that the seed of Garcinia kola had some degree of inhibitory effects on Staphylococcus aureus $(\mathrm{Gram}=+\mathrm{ve})$ and $E$. coli $(\mathrm{Gram}-\mathrm{ve})$, with no inhibitory effect on Candida albicans.

\section{Recommendations}

Considering the significant findings of this research, it is therefore necessary to conclude with the following recommendations.

There is need to investigate the antimicrobial potency of the plant against wider range of clinical isolates of pathogenic organisms in order to obtain a more accurate evaluation of the plants therapeutic potential. Further, it will be necessary to elucidate the mechanism of action and as well as their levels of toxicity to assess their clinical applicability.

\section{References}

[1]. Adebisi, A.A. (1997). Marketing and Post-harvest Constraint of the African Apple (Agbalumo). In Ladipo, D.O. and Denton, A. O. (Eds). Proceeding on the potential and conservation of Crysophyllumalbdium in Nigeria. NIHORT/NACGRAB/ CENARD.

[2]. Adewusi, H.A., (1997). The African star apple Chrysophyllumalbidum indigenous knowledge from Ibadan, south western Nigeria. In proceeding of a National workshop on the potentials of the star apple in Nigeria (eds), 25-33.

[3]. Adeuse-Poku, k., Nyinaku, F., Atise, V.Y., Awuah, R., Mensah, E.O., Nyantakyi, D., Owusu, H.K \&Agyenim-Boateng, B. (2003): Improving rural livelihoods within the context of sustainable development: case study of Goaso forest district. Tropenbos International Ghana, University of Amsterdam \& Institute of Renewable Natural Resources, pp.4.

[4]. Agyili, J., Sacande, M., and Kouame, C. (2006). Garcinia kolaHeckel. Seed Leaflet. Aiyelaagbe, I.O., and Adoela, A.O. (1993). Fruit trees for future agroforestry initiation in the humid zone of Nigeria: the farmer priority list. Paper presented at the ICRAF meeting on prioritization of MPTs for humid lowlands of West Africa. IITA, Ibadan, Nigeria.

[5]. Ajebesone, P.E. and Aina, J.O. (2004). Potential African Substances for Hops in Tropical Beer Brewing. J. Food Technolo. Afr. 9 (1): 13-16.

[6]. Akanmu, A.A and Bangsi, B.S (2008). Mriches of the forest: For health, life and spirit in africa. Monthly publication. 
[7]. Akerele, O.S., Obasuyi, O., Ebomoyi, M.I. and Umumarongie, O.H. (2007). Adie V.O. (2008). Weekend magazine - Health extra $24^{\text {th }}$ Ed: $32-38$.

[8]. Akinpelu, D.A and Kolawole, D.O. (2004). Phytochemistry and Antimicrobial Activity of leaf Extract of Piliostigmathonningli (Schum). Science focus, $7: 64-70$.

[9]. Akoachere, J.F., Ndip, R.N. and Chenwi, E.B (2002). Antibacterial Effect of ZingiberOfficinale and Garcinia kola on respiratory Tract pathogens. East Afr. Med. J. 79:588-592.

[10]. Akpulu, I.N ., Dada, J.D., Odama, E. 1 and Galadima, M. (1994). Antibacterial Activities of Aqueous Extracts of Some Nigeria Medicinal plants. Nig. J., Bot., 7:45-48.

[11]. Akunyilli, A.N., Houghton, D.J and Romana. (1991). Antibacterial activities of the stem bark of Kigeliapinnata. J. Ethnopharmacol., 2: $173: 177$.

[12]. Anegbeh, P.O., Iruka, C. and Nkirika, C. (2006). Enhancing germination of bitter cola (Garcinia kola) Heckel, prospects for Agroforestery farmers in the Niger delta. Sci. Africana. Vol.5 (No.1), April, 2006 @ Faculty of Science University of Port Harcourt.

[13]. Braide, V.P. (1991). Antihepatotoxic Biochemical effects of kola viron, a Bifflavonoid of Garcinia kola seeds. Phytotherapy Res., 5: 35-37.

[14]. Braide, V. and Vittrotio, G. (1989). Histological Alterrations by a Diet Containing seeds of Garcinia kola: Effects on liver, Kidney and intestine in the Rat. GedenbauursMophol. Jahrb, Leipzig. 1334: 95 - 101.

[15]. Colombo, M.L and Bosisio, E. (1996). Pharmacological Activities of Chelidoniummajus L (Papaveraceae). Pharmacol Res., 33: 127-134.

[16]. Dalziel, J.M. (1937). The useful Plants of west Tropical Africa. Crown Agents for the Colonies, London.

[17]. Delcampo, J., Amiuot, M.J. and Nguyen, C. (2000). Antimicrobial effects of Rosemary extracts. J . Food protect., 63: $1359-1368$.

[18]. Ebana, R.U, Madunagu, B.E, Ekpe, E.D., Otung, I.N. (1991). Microbiological exploitation of cardiac glycosides and alkaloids from Garcinia kola, Borreriaocymoides, kola nitida and citrus auratifolia. J.Appl. Bacteriol. 71 (5): 398-401.

[19]. Eisner, T. (1990). Chemical prospecting. A call for Action. In :Borman, F.h. and S.R keller, (Eds.), Ecology, Economics and Ethics: the Broken Circle, Yale University Press, New Haven, CT, pp : 105-110.

[20]. Eyog-Matig, O., Aoudji, A.K.N. and Linsoussi, C. (2007). Garcinia kola Heckel seeds dormancy breaking. App. Eco. Env. Res. 5 (1): 63-71.

[21]. Ezeifeka, G.O., Orji, M.U., Mbata, T.I and Patrick, A.O. (2004). Antimicrobial activity of Cajanascajan, Garcinia kola and Xylopiaaethiopica on pathogenic microorganisms; Biotech.,3 (1) 41-43.

[22]. F . A. O. (1996). Cote d'lvoire: country Report for the International Technical Conference of FAO on plant genetic resources, F.A.O, $75 \mathrm{pp}$.

[23]. F . D.A (1999). FDA/CFSAN/OPA: Agency Response Letter: GRAS Notice No. GRN000025 on the use of Garcinia kola seed in distillation@ http://vm. Cfsan.fda.gov/ rdb/opag025. Html

[24]. Faleyimu , O.I and Oluwalana, S.A. (2008). Medicinal value of forest plant seeds in Ogun state, Nigeria. Medicinal value of forest plant seeds

[25]. Fabeku, P.O. (2006). Traditional Medicine: the art ways and Practice In: Odugbemi, T. editor, Outlines and Pictures of Medical Plants from Nigeria. Uni. Of Lagos Press, P. 13-24.

[26]. Farombi, E.O. (2000). Mechanisms for the hepatoprotectiveaction ofkolaviron; Studies on hepatic enzymes, microsomal lipids lipid peroxidation in carbon tetrachloride-treated rats. Pharmacol. Res ., 42(1): 75-80

[27]. Gledhill. (1977). West African Trees. London Group Ltd. London 72pp.

[28]. Gill, L.S. (1992). Ethnomedicinal Uses of Plants in Nigeria. Benin City: Uniben Press, 276 pp.

[29]. Holmes, E.H. (1960). Notes on the plants of Liberia. Pharm. J. and Tr.. $3^{\text {rd }}$.series. 8. Pp 1877-79.

[30]. Ijeh, I.I., and Omodamiro, O.J. (2006). Anti - microbial effects of aqueous and ethanoicfractions of some local spicesOcimumgrasssitium and Xylopiaaethiopica. Recent progress in medicinal plants, 13:455-460.

[31]. Iwu, M. (1993). Handbook of African medicinal plants. CRC press, Boca Raton, FL., 32-38.

[32]. Iwu, M.M., Duncan, A.R. and Okunji, C.O. (1999). New Antimicrobials of plant Origin. In: Janick J. ed. Perspective on New Crops and New Uses. ASHS Press Alexandria, VA.

[33]. Iwu, M.W., Duncan, A.R. and Okunji, C.O. (1999). New Antimicrobials of plant Origin. In: Janick J. ed. Perspective on New Crops and New Uses. Alexandria, VA: Astispress., 459-462.

[34]. Iwu, M. and Igboko, A.V. (1982). Flavonoids of Garcinia kola seeds. J. Natural Product., 45:650-651.

[35]. Iwu, M.M., Igboko, O. A., Okunji, C.O and Tempesta, M.S. (1990). Antidiabetic and aldose reductase activities of Biflavanones of Garcinia kola. J. Pharm. Pharmacol. 42:290-292.

[36]. Iwu, M.M., Igboko, A.O. and Tempesta, M.S (1990). Biflavonoid Constituents of Garcinia kola roots. Fitoterapic 61 (2) : $178-181$. 